\title{
Explorations on the Abbasids Political Culture in Pursuit of Sustainable System of Governance in the Muslim World
}

\author{
Abdi O. Shuriye PhD \\ International Islamic University Malaysia \\ Email: shuriye@iium.edu.my; shuriye@hotmail.com
}

Doi:10.5901/mjss.2016.v7n4p

\section{Abstract}

Today democracy and good governance are absent from the Muslim world. Some attribute this to the religion of Islam itself while others, the mainstream of the world community, have attributed it to the Muslims themselves. The two however are intertwined and the later is on a course to a distractive paint of the former. History manifests itself in diverse ways and contemporary political outlook of the Muslim world is not a new phenomenon. The main objective of this study is to provide insights into the history of Muslim political thought; the Abbasid dynasty is the case under examination. One argues that the main contribution of the Abbasids is the development of a strong political system which has eventually led to a political stability and a steady economic growth. The political characteristics and the economic development during the Abbasid period, which was later recognized as the Golden Era in the Muslim political history, are the main focus of this work. This is crucial in order to understand the political backbone of the dynasty. Foreign relations which also contribute to the rise and the fall of Abbasids are also evaluated. Reassessment of the religious and political or territorial conflicts against other nations will be principal discourse in this work.

Keywords: Muslim political thought, Abbasids, Good governance

\section{Introduction}

The fall of Umayyad dynasty is followed by the coronation of someone from the Abbasid dynasty, who had blood associations with one of the uncles of the Prophet Muhammad Abbas. The Abbasids served the Muslim world for more than 500 years. They grew from an initial small size and had a great social influence into the large part of the East and West of the known world, from Bangladesh to Morocco. Unlike the Umayyads the Abbasid's political, military and economic system accommodated all the citizens under the dynasty, non-Arabs, Jews, Mawali, Persians, Turkish, Europeans and other religions and ethnicities have all participated in the political and economic process. This resulted great endeavor and cultural enrichment and therefore, this era witnessed not only cultural, economic and political development but at the same time led to scientific and technological gains. Foreign relations laid the development of a new civilization and knowledge; culture replaced desert mind set. Muslim merchants were able to trade over the revived road networks. Agricultural industry flourished and food production innovation was on the rise.

\section{The Rise of the Abbasid Dynasty}

After the end of the Khulafa' Al-Rashidin era, in 661, with bloodshed and political devastation, the Umayyads came to power. Mu'awiyah was the first Umayyad caliph and his appointment was not sanctioned by the Islamic system of election or appointment, rather it was based on his argument and persuasive ability of uniting the Muslim world of the time; particularly after the political upheavals against Ali. They ruled for 90 years, but they were exclusivist, nationalist, and not adhered seriously to the Islamic principles of good governance. Hence, the Abbasids defeated them and took over Damascus during the Revolution of the later. (Marin-Guzman, n.a.). Prior to this rebellion, Umayyads had faced rebelions from two main groups, namely, the Kharijites and Shiites. The Kharijites allegedly fought for equality between the Muslims, social equality? and argued that the selection of the caliph had to be based on talent rather than ethnic origin. They urged the Umayyad to return to the Qur'an and the way of Prophet Muhammad in the political process, from which the Umayyads had deviated. The Shiites, on the other hand, were with the opinion that the political power had to be inherited by the family of the Prophet. They believed that the descendants of Ali who embodied the grace inherited from Prophet Muhammad had to be chosen as the political leader of the community. These two uncoordinated rebellions were however unsuccessful and easily suppressed by the Umayyad (Asimov and Bosworth, 1998). 


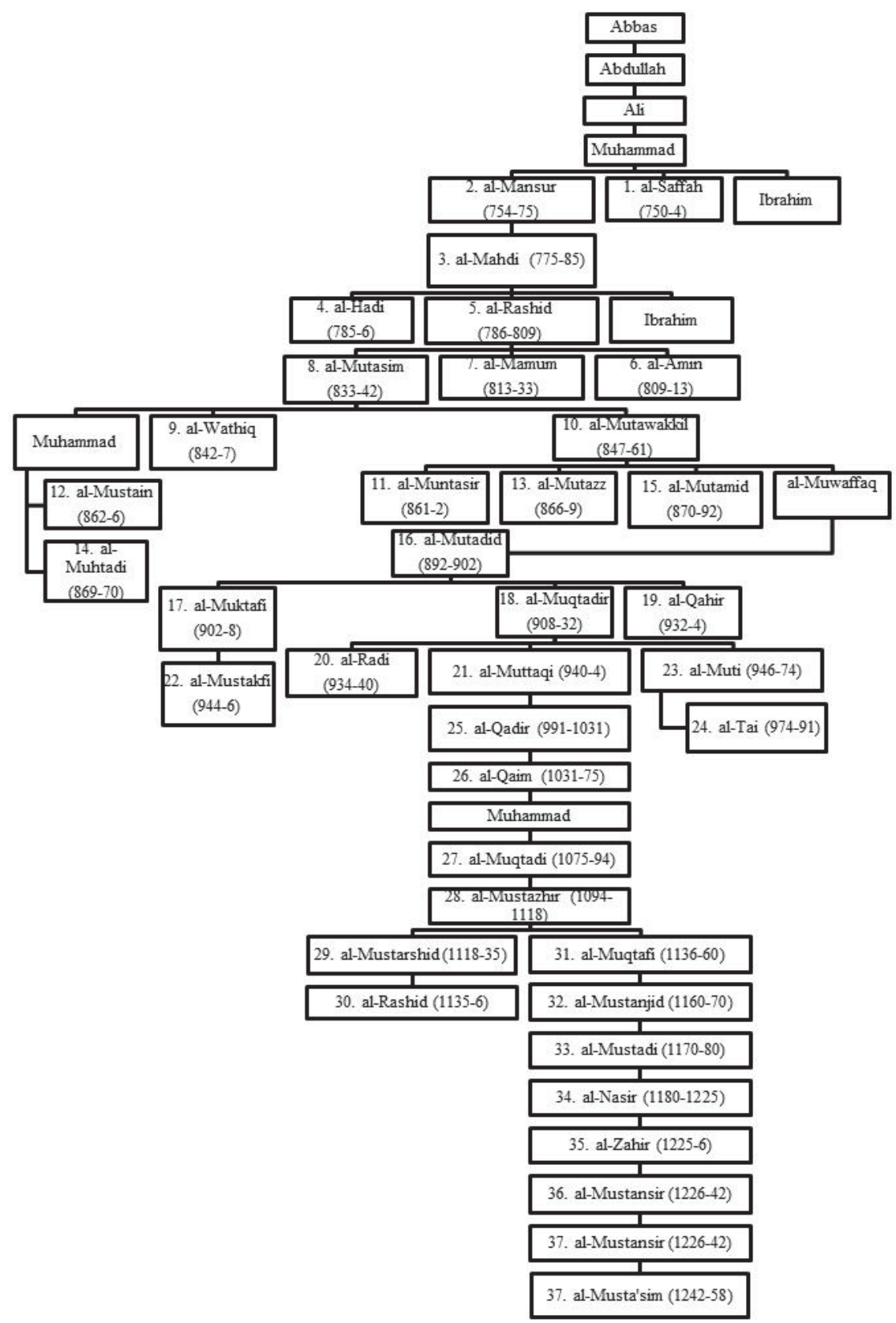

Figure 1: Genealogy of the Abbasids (Rahman, 1989).

As time passed on, there was a gradual built up on resentment from the opponents of the government and especially non-Arabs. In North Africa, Spain and in Persian territories, people were not satisfied with the mistreatments regarding the poll-tax or jizya. Umayyads insisted on heavy taxes from the non-Muslims which was higher than the zakat collected from the Muslim citizens. This law led a lot of non-Muslims to convert to Islam for financial advantages 
particularly for lower tax. Then a new law was introduced to tax the non-Arabs higher even after they converted to Islam. This was indeed un-Islamic and directly contradicted the Shari'ah.

The Abbasids exploited these weaknesses to expedite the fall of the Umayads. Secret meetings were held to ensure the success of their agenda. Abbasid also sought help from the Persians capitalizing on the Umayyads' biased attitude towards non-Arabs; which made Persians and other cultures to be treated as second class citizens. In 730s, the Abbasids sent secret missionaries to the Persians for their support. , the Abbasids used the Persians Skillfully to increase their strength. The Persians were attracted to the Abbasids because they were considered as part of the Prophet's household; which attracted not only the Persians but also the Shiites. In fact, in the political spectrum of the time, the Persians were sympathetic to the Shiites (Elsohemy, 2004).

The Abbasids also claimed that one of the descendent of 'Ali had transferred the right to rule to Abbasids family. This propaganda seems to give them legitimate right as the rightful rulers of Muslim world. The political movement to overthrow the Umayyads was based in Kufa (Iraq) and remained secret until the favorable moment come. In 747 C.E., Imam Ibrahim who led Abbasid movement ordered Abu Muslim to prepare for commencement of the revolution in Khurasan Provence. Khurasan was chosen as the first place to start the revolution due to the strong support from nonArab tribes and mawalis. After the successful capture of Persia, Abu Muslim continued to the rest of territories including Iraq. The Abbasid forces completely defeated the Umayyad army during the Battle of the Zab in early 750 and took control of Damascus (Glubb, 1985; Sicker, 2000). This battle was led by Abu al-Abbas al-Saffah who became the first Abbasid caliph in 750 C.E and had proudly said in his speech in the Jamia Mosque of Kufa claiming: "Allah has strengthened His religion through us and we have been made its protectors and fort. We are defending the faith and fighting for it. Allah has made us steadfast in piety and purification. He has favored us with kinship of the Holy Prophet Muhammad (S.A.W) and thus made us the most deserving family for Khilafat" (Akbar Abadi, 2009).

The Abbasids were in power from 750 to $1258 \mathrm{C} . \mathrm{E}$, and their line of leadership succession is shown in the diagram below. A new capital was established and Baghdad became the centre of the world; a cultured city of political weight. Meanwhile, the Abbasid rule brought a new dimension. This time, the Arabs became underdog as Persians and the Turks influenced the political system and changed the political and cultural fields of the Abbasid Empire (Elsohemy, 2004). This was proved with the appointment of Abu Muslim, who was a Persian, as the head of the army during the first Caliph in the Abbasid Era (The Saylor Foundation, n.a.).

It is necessary to give a reference somewhere in the paragraph above to the table below. Otherwise, no one will understand why it is placed in the manuscript.

\section{Good Governance and Abbasid's Political Culture}

The taxonomy and history of Islamic political thought has no one catalog; rather it is dichotomous and full of bumps, downwards and upwards. From the time of Prophet Muhammad to our present day political turmoil has reigned in the Muslim world. There where however, occasions in history, as mentioned, within which Muslims observed political stability and development. Abbasid's government was indeed relatively stable; this was due to multiple variables including their style of governance.

This section of the research studies the concept of good governance within the Abbasid's political culture. Today the term good governance, as we have mentioned, is absent in the political arena of the Muslim world. Studies have been conducted on various Muslim nations including Afghanistan. Elahi (2009) study to estimate the measurement for good governance is relevant. In his study, Elahi argued that interpreting governance as a process in the Muslim world is not rational and indeed state and government should not be considered synonymous. His study concludes that it is the role of civil society organizations to promote good governance in the developing world. (Elahi, 2009).

For the sake of precision, good governance is the transparent and accountable management of human, natural, economic and financial resources for the purposes of equitable and sustainable development (Policy Document 2011). In the past and current development of world politics, good governance has received extensive attention. In fact, it is a dynamic connotation and according to the Oxford Dictionary it advocates the way in which a country is governed (Wehmeier, 2000).

The history of political Islam and Western colonization has contributed to wider contrasting views on the notion in the Muslim world. Nonetheless, the concept of good governance, in Islamic political thought, should be studied and implemented within the various sets of good values.

The constituents of the Qur'an, as a source of good governance in Islam, are the 'aqidah (faith), shari'ah and akhlaq (Islamic moral system). Good governance therefore in Islam is a political system which reads all the three tenets together. Hence, if the political system provides human benefit within these three constituents of the Qur'an then it is a 
good system. In describing good governance, both the Qur'an and the hadith talk of promoting benefits and preventing harm within the Islamic value systems.

The Abbasids eluded from the political and administrative mistakes of the Umayyad and subsequently discarded the costmary political regulations and absolutism of the Umayyad; for this they established an open and representative government. They accommodated the Turks, the Shiites, the Mawalis and Mu'tazilites. They initiated openness toward other races, religions and regions. This new approach was strategically designed mainly by the second Caliph and further consolidated by the fifth caliph and made the Abbasids extremely efficient government. Besides, their system of political administration was overwhelmingly inclusive.

In the history of the world each regime comes with its new political systems and administrative initiatives, Abbasids were not exceptional. They, with immediate effect, reinstated the role of Islam, and considered themselves as the sole custodian of the religion. Another salient feature was that the Abbasid government was more diverse compared to the Umayyad. There was no special favor given to the Arab military or aristocrats even those from the ranks of conquering Arabs. Although the Arabs had a large role in the government, but Persians, Egyptians and others were given highranked positions. Unlike the Umayyad, the Abbasids were not a conquering dynasty, but they administered the territories they ruled of diverse linguistics, ethnic and cultural groups. In addition, they heavily relied on Persian techniques of statecraft to design their administration (Bentley and Ziegler, 2003).

However, in their first century of their rule they managed to keep the main political power in the hands of the Arabs. The borders of Islam were also strengthened and established bridgeheads to further expand the religion. During this period, Arabic language finally became the language of the empire, and became the medium of Islamic culture for all its advocates, of all origins (Endress, 2006). However, political advancement was open to all despite the facts that Abbasids were Arabs and Arabic was the official language. This is because the Abbasid dynasty had transformed into a Muslim state where Arabs do not have assured preferment (Sicker, 2000).

As-Safah, the first caliph, was highly influenced by the Persians, established the capital at Kufa, which had been part of Persia for hundred years. The Abbasid Dynasty represented Persian influence in the Middle East, which caused this reorientation to have serious impacts in the Arab-dominated western part of the dynasty (Sicker, 2000). After asSaffah, his brother and successor al-Mansour moved the political and cultural center to the East. Baghdad was made the new capital in year 754, and central authority was from the court at Baghdad. The caliph's palace was at the heart of the city, which was strategically located from where the instructions could be easily flowed to the entire empire. (Endress, 2006).

In the administration of the Abbasid state, caliph stood as the head of the state, being the fountainhead of all powers. He delegated the exercise of the civil authority to a wazir (vizir); the judicial authority to a qadi (judge) in the judicial administration; and the military power to an amir (general) in the military organization; but the caliph remained as the final arbiter of all governmental affairs. Governmental bureau included bureau of taxes which is one of the sources of revenue for the government; accounts office; chancery office which handled official and political documents; police department was headed by a high officer; a board for the inspection of grievances which was a kind of court of appeal in the administrative and political departments; and postal department which was a significant feature of the Abbasid government. Postal department was originally designed to serve the interests of the state. A post office was provided in every provincial capital, where the system covered the important routes connecting the leading centers of the empire. The services they provided included the transportation of troops with their baggage, the service to make the payment of a substantial sum, and the support for itineraries of the whole empire indicating various stations and intervening distances (Kennedy, 1986).

Governors were appointed in every province to represent the caliph and implement his financial and political policies. In local communities, Ulama' (people having religious knowledge) and Qadis (judges) set moral standards and resolved disputes. They had a formal education in the study of the Qur'an and shari'ah. Ulama' takes part in the development of public policy according to the Qur'an and shari'ah. Qadis, on the other hand, deal with court cases and makes decisions based on the Qur'an and shari'ah. Both Ulama' and Qadis became influential officials who assisted in ensuring widespread observance of Islamic values. Apart from that, a standing army was kept, and bureaucratic ministries taking charge of the finance, coinage, taxation and postal service were established (Bentley and Ziegler, 2003).

\section{Economic System of the Abbasid}

\subsection{Trade System and Manufacturing Activities}

The Umayyads and Abbasids created a wide zone of trade, exchange, and communication. It stretched from India to 
Iberia; the commerce in the zone was a vital economic stimulus for the Islamic world both in the countryside and the cities. Hundreds of vessels were placed along Baghdad's waterfronts including war-ships and pleasure crafts. There were goods like porcelain, silk and musk from China; spices, dyes and minerals coming from India and Malaya; rubies, fabrics, lapis lazuli and slaves from the land of Turks in Central Asia; honey, wax, furs and white slaves coming from Scandinavia and Russia; and ivory, gold dust and black slaves from eastern Africa; going into the bazars of the city. There were also domestic items from the provinces of the empire itself sent by caravan such as rice, grain and linen from Egypt; glass, metal ware and fruits from Syria; pearls, weapons and brocade from Arabia, perfumes, silks and vegetables from Persia (Hitti, 1886).

The expanding state became prosperous with trading cities of central Asia and other parts of the world where Muslim merchants were able to trade over the revived silk roads. These extensive road networks were built by imperial authorities in India, Persia and Mediterranean basin during the classical era; which were maintained by the Umayyad and Abbasid rulers. This is because the road networks provided great routes for military forces and administrative officials to travel through the dynasty and made excellent highways for merchants, missionaries and pilgrims since travelling along these roads were speedy and efficient (Bentley and Ziegler, 2003). The manufacture of camel saddles spread throughout Arabia, southwest and central Asia, and North Africa where camels were the favored animals of burden in deserts and dry regions. The major cities of the Islamic world built and maintained caravanserais to offer lodging, food and water for caravan merchants. Other items manufactured during this time were leather goods, metal items, perfumes and papers (Bentley and Ziegler, 2003).

\subsection{Agricultural Production}

Agricultural products were the major source of economy during the Abbasid's reign. The products include dates, rice, sugarcane, and varieties of grains, fruits and vegetables. The era brought innovations in food production and diet, and one of the first novelties was the cultivation of rice. Prior to that, rice was unknown to Muslims, Roman and Byzantine Empire. Soon afterwards, rice became a staple cereal in irrigated lands such as Egyptian Delta. Another commodity that Muslims popularized was sugar. Sugar cane was grown in Iraq and a bit of sugar was imported to the Roman Empire, but it never replaced honey as a sweetener. On the other hand, Muslims preferred sugar over honey, therefore sugarcane was planted and the sugar was exported to the Byzantine Empire and to Europe. Ever since, the choice of fruits and vegetables was greatly expanded. Many new fruits made their way from Iran, India and China to the west such as peaches, apricots, pomegranates, limes, lemons and bitter oranges. The increase of transplanted crops gave a more varied diet and an increased quantity of food available (Sitemason, n. a.).

Besides providing a dramatic increase in food supplies, some new crops had been developed for industrial use, and the most important one was cotton, which became the basis for textile industry. Dyes yielded from indigo and henna were widely used by textile manufacturers. Textile production was one of the biggest innovations of the Abbasids where they distributed the cultivation of cotton to Iraq, North Africa, and especially to Egypt (Bentley and Ziegler, 2003).

\subsection{Long-Distance Trading, Banking and Coinage Systems}

Long-distance trade was an important aspect in the Abbasid economy. They controlled the area extending eastward to India and China, and to westward to Morocco and Umayyad Spain. The movement of products and goods was safeguarded by the political unity of the Abbasid dynasty and the effectiveness of Arabic language all the way. The trade mainly moved by sea, and the rest of it was done by caravans of pack animals (Sitemason, n. a.).

The commercial economy of the Abbasids was stimulated by banking system, which was conducted on a much larger scale of business and a more extensive range of services in the Abbasid Empire. The banks lent money to entrepreneurs and at the same time acted as brokers for investments and currency exchange. The use of letter of credit (check) was adopted. Multiple branches were established where the merchants could draw letters of credit in one city and cash them in another so that it would be convenient for them to settle accounts with distant business partners without having to deal in cash. Abbasid entrepreneurs preferred to invest their resources in groups instead of solo ventures, so that they could distribute the risks and absorb losses easier. Long-distance trade was established due to the improved transportation, expanded banking services and refined techniques of business organization (Bentley and Ziegler, 2003).

During the Abbasid era, a uniform coinage system was implemented to ensure a more convenient trading system. When the capital of the Abbasid dynasty was moved to Baghdad by al-Mansour, the gold mint was moved to the new capital. The period was when the silver coins or dirham were minted with the names of the influential person. In the Harun ar-Rashid's period, he minted the dinars with the names of the Egyptian governors, and this period witnessed at least two 
active mints in the empire, both in Baghdad and Egypt. Al-Ma'moun attempted to do experiment with different kinds of coins. He managed to improve the appearance of the coins with his highly developed sense of art, and the design continued to be used for several succeeding centuries (Ali, 2004).

\subsection{Taxation System}

Collecting revenues from the above-mentioned system was not the only means of generating revenue adopted during the Abbasids period. The taxation included the Zakats collected from the Muslims, al-Jizyah from the non-Muslims and tax for land owners. The Zakat was collected by 'Amils and distributed in the same town instead of bringing it out of the town; while al-Jizyah was to be imposed on healthy non-Muslim men citizens only. During the Abbasids Al-Jizyah was fixed at the rate of 48 dirhams per year for the rich, 24 for the middle class and 12 for the laborers. Lands were divided into two: al-'Ushr and al-Kharaj, all Arabs' lands, non-Arab Muslims' lands, and non-Arabs' lands distributed among the conquerors were categorized under al-'Ushr; and those lands which were conquered by force from the non-Arabs and were left by the conquerors became al-Kharaj lands. Under this period, the collection of taxes was left in the hands of contractors to return a fixed sum of money. This caused various kinds of threats since it had led to unauthorized exactions by the contractors (Husaini, 1968).

The Zakat was imposed on gold, silver, herds, and other forms of property which were able to be augmented through natural increase or by investment. Money collected was distributed from the central treasury to the poor, the stranger, the orphan, slaves and captives, and volunteers for the holy war. The revenue collected from other main sources of public income was used by the caliph to pay the troops, the maintenance of mosques, roads and bridges, and for the general benefit of the Muslim community (Hitti, 1970).

\section{Theological Influence on the Abbasids: The Shiites and Mu'tazila}

Similar to our today's world, theological interpretation of Islam played a major role in politics during the Abbasid rule particularly in the early parts of the dynasty. These groups were indeed complex and uneven. As mentioned, Abbasids were brought to power by the call for the rights of ahl al-Bayt (the family of the prophet); a Shiite call and movement. Years after, the Abbasids had to take great pain to emphasize their position as the members of Prophet's household. That was political relevant at the time, at the same time the caliph was regarded as the Imam, but the claim of imamate by the Abbasid caliphs has collided against the claim of Shiite traditions of imamhood.

The Abbasids were not aware that the Shiites and their prominent members were already regarded as imams during this time. One of the most famous Shiite imams during the Abbasid time was Ja'far as-Sadiq (765 C.E.), the sixth of their twelve prominent imams. He was known to have made contributions during his lifetime towards defining the doctrinal bases of the community which regarded him as the imam. This caused problems for the Abbasids to discipline their followers whom the Shiites considered to be their imams since the paths of the Shi'ites and the Abbasid had diverged, and Ja'far had made effort to consolidate the position of his Shi'as as a distinct community. Therefore, the Abbasid caliphs had to ensure that they were acceptable to the Muslim community at large. The Abbasids were aware of the fact that, Shiites were against the authorities, and hide their real political and theological beliefs (Zaman, 1997).

On the contrary, the Mu'tazila had a bigger role and influence in the political process of the Abbasids. Mu'tazila is the name given to the Movement by their adversaries. They however call themselves "people of Justice and Tawheed". Historically speaking, the Abbasid period saw the emergence of various religious scholars and disciplines increased influence by religious elites on the political system. Mu'tazila influenced the Abbasid political system by introducing the new ideology of how Muslims should think about their religion and in many occasions went on loggerheads against Muslim traditionalists and political elites as they were declared as heretic as they used philosophical and rationalistic approach to interpret religion.

Mu'tazila also attempted to fuse the idea of free will (khiyar) with theism, and were of the view that things were not good and bad because God had made them so, but God made distinction between good things and bad things of the good of His people (Sharif, M.M, 1983). Hence, religious entities had their influence on Abbasid's political system. Early Abbasid era witnessed flourish of Mu'tazila which has in fact emerged during the Umayyad caliphate. They developed a theological system using pure intellect. The translation of books which were originally in Greek, Indian and Chinese languages paved the way for new rational development of the thinking Muslims and brought new viewpoints in Muslim intellectualism. In the time of Caliph Harun ar-Rashid, the Mu'tazila strived to attain power and to dominate theological scene. The new political and intellectual environment provided opportunity for Mu'tazila to consolidate their position. The Mu'tazila tried to rationalize faith by interpreting religion on rational grounds which caused opposition by the traditionalists 
and the caliphs. In the end, Al-Mutawakkil persecuted them as heretic; particularly on the issue of createdness of the Qur'an (Muhammad, 2012).

Nonetheless, with some Abbasid caliphs the Mu'tazila enjoyed the status of an "official" theology; which then coalesced into two main schools in Baghdad and Basra in the $10^{\text {th }}$ century. In the $14^{\text {th }}$ century, the movement gradually fell out of favor of the Sunnis and finally disappeared. However, the impact of this Mu'tazila school of thought remained to be felt among the Shiites, where the influence lingered through centuries and can even be seen today (Schmidtke, 2008).

\section{Foreign Relations}

During 3rd Century AH (9th C.E), the world was ruled by four great powers. They were the king of the Arabia, the king of China, the king of al-Rum (The Byzantine) and the king of India (al-Tajir, 1994). However the biggest ruler at that time was the Abbasid Caliph followed by the Chinese emperor, Byzantine and lastly Bilahara, the king of Southwest India. Other than this great ruler, a few more was observed from Central Asia, Western Europe and sub-Saharan Africa. Western Europe at that time was divided into Kingdoms, Church and commercial city-states. Details on Abbasids' relations with those powers will be provided in Section 6.1 until 6.3 .

\subsection{The Abbasids and Byzantine}

Byzantine is an empire ruled by the Roman emperor. The empire's name derivesd from a modest market town and fishing village, Byzantion. Byzantine Empire was located at a strategic location and blessed with a magnificent natural harbor known as the Golden Horn. The strategic location enabled Byzantine to control the strait of water leading from the Black Sea to the Sea of Marmara and beyond to the Dardanelles, the Aegean Sea and the Mediterranean. The Byzantine Empire was a great enemy to Muslims world. The war between Muslims and Byzantine started during the time of Prophet Muhammad (SAW). The wars were motivated towards the supremacy in the Eastern Mediterranean. The Byzantine used to form a coalition with some Arabs in Syria to attack the Muslim state in Medina during Prophet Muhammad PBUH period. This action led to continuous war between these two kingdoms. During Umayyad caliphate, Muslims defeated the Byzantine in Syria, North Africa and some of the Mediterranean Islands.

When Abbasid family took over the leadership of Muslims world from Umayyad in 750 C.E., the wars against Byzantine were limited to the eastern waters of the Mediterranean Sea. During the period of al-Ma'mun caliphate, a deal was made to seek permission from the Byzantine's emperor to deliver Greeks Manuscripts to the Muslims. Although the wars continued until 1180 C.E., actions were taken by both rulers to ensure the smoothness in trade. In addition to that, these two powers also have understanding in the field of religion. For example, the Byzantine church agreed to monitor a lot of Christians who were Orthodox in Muslim territories, mainly in Syria and Egypt. Unlike the Fatimids, Abbasids allowed establishment of Christian Holly places inside their territories (Kennedy, 2001). In addition to that, the Byzantine concerns on the safety of travelers who regularly visited their holy places in Islamic territories had led to understanding in religion matters with Abbasid (Norwich, 1997).

\subsection{Abbasid-Carolingian Alliance}

In ninth century, Carolingian and Abbasids of West and East respectively were known as the most powerful imperial and stand supreme in world affairs. The relations between the Carolingians and Abbasids started after the fall of Umayyad dynasty in Damascus. This relation was nothing more than just to protect their self-interest. For example, Carolingian needed Abbasids as a possible associate against Byzantine while Abbasids needed Carolingian to compete with other Islamic power in Southern Spain, which was Umayyads. During Caliph Harun al-Rashid, series of embassies, exchange of presents, and joint military forces were formed between the Carolingian Empire and Abbasid (Hitti, 1886). As mentioned by the Frankish author, the king of the West received rich gifts such as fabrics, aromatics, clocks and elephant from the King of Persia, Aoron. In addition to that there was also great commercial exchange between the Carolingian and Abbasids Empire. The wide spread of Arabic coins and gold in Carolingian is a proof to the exchange (Goody, 2004).

\subsection{Abbasids and China}

China was a huge empire located in the East of Asia. The relationship between Chinese and the other part of the world such as Western Europe and Arabian Peninsula started during the Han Dynasty. The Han's traveler Zhang Qian in 115 
B.C. visited the Central Asia and the West Region. He travelled through the road known as "the Silk Road". The Arab people at the same time also had hewed out the ship route from the Red Sea and the Gulf, through the India Peninsular and the Malay Peninsula to the South of China. Although the travelling activities started during the Han Dynasty, the communications between China and the Arab world only started during the Tang Dynasty. The opening of the "Spice Route" had considerably increased the trade activities between the China and Arab countries. The holy Prophet Muhammad (S.A.W) referred to China as a place for a few activities such as trading and education. The relations between the Arabic world and China is evidenced with the exchange of envoys especially during the third Caliph (AlSaadi, 2012).

The Tang's interest however was not just limited to the trading business. They were also interested in enlarging their geographical territory to the Arab peninsular which was a strategic location for business and tremendously rich at that time. Their expansion in the Arabian peninsula was halted when they lost in the Battle of Talas in 751 C.E to the Muslims army, Tibetan and Uyghur led by Abu Abbas also known as al-Saffah from the Abbasid family. The Battle of Talas significantly contributed to the positive climate changes in the political fortunes of the rival sides and economic development along the Silk Road (Al-Saadi, 2012). In addition to that, Battle of Talas was the key event in the history of paper making in Abbasids dynasty.

A year after the Battle of Talas, the Abbasid's caliphal-Saffah sent envoys to China. This brings about change in their relationship from military and political struggle to a peaceful coexistence and corporation in economics and trading. In terms of military forces, Abbasids sent their army to China to help Tang Suzong quell the riot, which was "An Shi Rebellion" in 757 C.E. The relationship between China and the Abbasid's first caliphate was continued by the second caliph al-Mansur. Al-Mansur said: "We are lucky enough to have the Tigris River to get touch with the faraway lands, like China" (Needham, 1954). The good relationships between these two empires allowed knowledge exchange and Arab merchants conducted trade in various cities of China such as Guangzhou, Quanzhou and Yangzhou.

\section{Conclusion}

Obviously, the Abbasid dynasty is an example of good governance for Muslims. Our aim in this research is to identify which factors led to political and economic stability in Abbasid era which was considered by the world of today as the Golden age for Muslim political system and governance. Among the multitude factors, rich tradition of knowledge, an appreciation for culture and an acceptance of foreign ideas were the key contributors. Abbasid dynasty became stronger with the passage of time mainly because diverse people of the border lands started interacting with each other, offering new thoughts, scientific discoveries, writing and a host of other fundamental achievements. Through this cultural interaction the Abbasid dynasty encouraged a society that desired and appreciated knowledge, a government that invested in knowledge, and it created a stable trade system in which scholars from China to Iran and to Turkey would come together to venture into the new open intellectual world. The government in the Abbasid dynasty helped in replication, redistribution and preservation of written sources through translation of good classical work. The work of translators and their role in preserving documents was a fundamental contribution to a society and Abbasid dynasty. The silk road was one important channel that aided in transfer of knowledge, ideas and goods, but it was only successful due to the stability that Abbasid government created in the region. Governments in the Muslim world today need to pick the progressive strategies of the Abbasid dynasty in order to lead their nation with good governance.

\section{References}

Akbar Abadi, M. S. (2009). An Analytical and Critical Study of Islamic History: The Rise and Fall of Muslims (From the Pious Caliphs to Abbasid Spain and Moghal Dynasties). Adam Publishers \& Distributors: New Delhi, India.

Ali, W. (2004). Islamic Coins during the Umayyad, Abbasid, Andalusian and Fatimid Dynasties. FSTC Limited: United Kingdom.

Al-Saadi, A. S. (2012). The Origins of Omani-China Friendship: A Historical Review. Journal of Middle Eastern and Islamic Studies (in Asia), 6 (2), 84-105.

Asimov, M. S. and Bosworth, C. E. (1998). History of Civilizations of Central Asia. The Age of Achievement: A. D. 750 to the End of the Fifteenth Century, Volume IV, UNESCO Publishing: Paris.

Bentley, J. H. and Ziegler, H. F. (2003). A New Society: The Expansive Realm of Islam. McGraw-Hill Higher Education.

Elsohemy, D. (2004). The Characteristics of the Abbasid Empire. Dar Al-Arqam Islamic Centre: History of Islamic State.

Endress, G. (2006). Islam: A Historical Introduction. New Age Books: India.

Glubb, J. (1985). A Short History of the Arab Peoples. Stein and Day: New York.

Goody, J. (2004). Islam in Europe. Polity Press: Cambridge.

Hasan, M. (1988). History of Islam (Classical Period 1206-1900 C. E.). Islamic Publications (Private) Limited: Lahore. 
History and Literature. (n. a.). The Abbasid Empire and the Crusades. Retrieved from http://www.pourlhistoire.com/abbasids.html Hitti, P. K. (1970). History of the Arabs. Macmillan Education Limited: London.

Hitti, P. K. (1886). The Arabs: A Short History. Regnery Gateway: Washington, D.C.

Husaini, S. A. Q. (1968). The Constitution of the Arab Empire. Sh. Muhammad Ashraf: Lahore.

Jones, R. C. (2004). The Crusades: A Brief History (1095-1291). Acworth, Georgia.

Kennedy, H. (1986). The Prophet and the Age of the Caliphates. Longman Publishing Group: New York.

Marín-Guzmán, R. (n.a.). Arab Tribes, the Umayyad Dynasty, and the Abbasid Revolution. The American Journal of Islamic Social Sciences, 21 (4), 57-96.

Muhammad, A. (2012). Mutazila-Heresy; Theological and Rationalist Mutazila; Al-Mamun, Abbasid Caliph; Al-Mutawakkil, Abbasid Caliph; the Traditionalists. Middle-East Journal of Scientific Research, 12 (7), 1031-1038.

Muir, W. (1924). The Caliphate: Its Rise, Decline, and Fall. AMS Press Incorporated: New York.

Needham, J. (1954). Science and Civilization in China. Vol. 1. Cambridge University Press: Cambridge.

Norwich, J. J. (1997). A Short History of Byzantium. Time-Life Books: New York.

The Saylor Foundation. (n. a.) The Abbasid Dynasty: The Golden Age of Islamic Civilization. Retrieved from http://www.saylor.org/hist101

Schmidtke, S. (2008). Theological Rationalism in the Medieval World of Islam. The Bulletin of Middle-East Medievalists, 20 (1), 17-29.

Sicker, M. (2000). The Islamic World in Ascendancy: From the Arab Conquests to the Siege of Vienna. Praeger: Wesport, Connecticut.

Sitemason. (n. a.). Chapter Twenty Two: Abbasid Civilization and the Culture of Islam. Retrieved from http://sitemason.vanderbilt.edu/files/jLTKV2/Chapter\%20TwentyTwo.\%20Abbasid\%20Civilization\%20and\%20the\%20Culture\%20 of\%20lslam.pdf

Tanner, J. R., Previte-Orton, C. W., Brooke, Z. N. (1923). The Cambridge Medieval History. Cambridge at the University Press.

Young, M. J. L., Latham, J. D., Serjeant, R. B. (2006). Religion, Learning and Science in the Abbasid Period. Cambridge University Press.

Zaman, M. Q. (1997) Religion and Politics under the Early Abbasids: The Emergence of the Proto-Sunni Elite. Brill: The Netherlands. 